\title{
Economia e trabalho no sul de Minas no século XIX ${ }^{1}$
}

\author{
Isaías Pascoal ${ }^{2}$
}

\begin{abstract}
Resumo
O conhecimento da forma como se estruturaram a produção econômica e a organização do trabalho em Minas Gerais, século XIX, vem se ampliando nos últimos decênios, obrigando a uma revisão das teses tradicionais. Embora reconheça o valor inestimável dos estudos econômicos, em nível geral e local, este artigo enfatiza a importância de se levar em conta fatores que se encontram além do recorte econômico, para compor um quadro mais complexo e rico que permita o entendimento do maior número possível de variáveis responsáveis pela forma como a economia e o trabalho, efetivamente, se organizaram num arranjo que permitiu a sua reprodução ao longo da maior parte do século XIX.
\end{abstract}

Palavras-chave: Escravidão - Século XIX; Economia - Minas Gerais; Trabalho - Organização.

\section{Abstract}

\section{Economy and labour in the south of Minas in century XIX}

The knowledge of how the economic production and organization of the work in Minas Gerais were structuralized in the century XIX has been enlarging in the last decades, compelling to a review of traditional theses. However, this article recognizes the inestimable value of the economic studies, in general and local level, it emphasizes the importance of taking in account factors that are beyond the economic perspective, to compose a richer and more complex picture that allows the understandment of the greater number of variables as possible that are responsible for the way the economy and labour, effectively, were organized in an arrange that allowed their reproduction beyond the XIX century.

Key words: Slavery; Economy; Reproduction; Labour; Revision. JEL R100, R200, Z100, J210, N900.

Uma notável produção de pesquisa tem sido feita em Minas Gerais, nos últimos decênios, com a finalidade de entender a forma como economia e trabalho aí se estruturaram no século XIX. Teses tradicionais sobre Minas perderam força ou foram abandonadas. Grande parte dos estudos se concentra nos campos econômico, demográfico e da organização do trabalho. Embora sejam de valor inestimável, é importante lançar os olhos em outras direções, para outros campos, capazes de fornecer pistas para um entendimento mais profundo da forma como economia e trabalho se tornaram elementos fundamentais para transformar Minas num modelo que exige redefinições em várias interpretações teóricas que comumente explicavam sua realidade social.

(1) Trabalho recebido em outubro de 2006 e aprovado em março de 2007.

(2) Professor da Escola Agrotécnica Federal de Inconfidentes - MG. Doutor em Ciências Sociais pelo Instituto de Filosofia e Ciências Humanas (IFCH) da Universidade Estadual de Campinas (Unicamp). 


\section{Uma passagem pela historiografia: rompendo modelos, ampliando horizontes}

As teses mais tradicionais sobre economia e sociedade mineiras enfatizavam a importância da mineração no século XVIII, assentada no trabalho escravo. Este modelo econômico teria entrado em crise no último quartel do século e iniciado um lento trânsito para a agropecuária, culminando na economia cafeeira que fez a província reencontrar-se com a prosperidade e com o trabalho escravo. Ficam obscurecidos, quase irrelevantes, neste esquema a pujança do setor dedicado à produção de artigos de subsistência, consumidos no local ou comercializados em várias praças, e o seu apego à escravidão na maior parte do século XIX, além de não ter a devida atenção a presença de outros setores da economia que, somados ao aparecimento da cafeicultura e à recuperação da atividade mineradora, expressavam o panorama de uma realidade econômica bastante diversificada.

Hoje já há consenso sobre a importância da economia mercantil de subsistência e do trabalho escravo em todo o Estado de Minas, sobretudo na sua parte meridional, graças a todo um esforço de pesquisa e superação de perspectivas teóricas antigas feito ao longo dos últimos 30 anos.

No conjunto de trabalhos que enfoca a questão, sem lhe atribuir a importância que posteriormente veio a ganhar, destacam-se os de Francisco Iglesias e Caio Prado Júnior. O primeiro trata da questão atestando a importância da mineração para o conjunto da economia mineira no século XVIII. Em crise essa, a agropecuária assume papel importante no início do século XIX, com destaque para atividades não voltadas à exportação. Todavia, em função, talvez, do formato muito genérico e abrangente do artigo, fica obscurecida a importância desse setor no conjunto das atividades econômicas de Minas no século XIX. Em alguns momentos, afirmação como a que se segue, se torna muito significativa:

No capítulo da lavoura, temos o seu incremento pela desocupação de fatores produtivos. Ela não chega, entretanto, à pujança de outras áreas do país, pois a condição de capitania central, emperra o comércio. Desenvolve-se a lavoura de subsistência, não a de produtos de exportação - a chamada grande lavoura. As distâncias a serem percorridas pelas mercadorias mineiras e os pagamentos em que elas importam fazem que não possam disputar com as da faixa litorânea. Das lavouras de mais significado econômico, só o algodão teve êxito ainda no século XVIII, para atender às necessidades dos filatórios; as demais culturas destinam-se ao consumo imediato; terá início, então a conquista de terras para o café (Iglesias, 1985, p. 362-412).

Pelo exposto, a agricultura só se desenvolve pela desocupação de fatores produtivos. A referência é ao ouro e aos escravos que antes se ocupavam dele. A afirmação de que a lavoura mineira não tem a pujança das que se desenvolveram 
em outras áreas em função da condição geográfica central de Minas (seria porque não se desenvolveu como economia de exportação - a grande lavoura?) não é corroborada pelos resultados de pesquisas mais recentes. A afirmação final de que as demais culturas destinam-se ao consumo imediato; terá início, então a conquista de terras para o café desconhece o lapso de tempo existente entre uma e outra. Não estaria aí uma perspectiva teórica que sobreleva as atividades voltadas à exportação e que, por mais que não desconheça a existência de atividades não ligadas a ela, não lhes atribui a necessária relevância?

Caio Prado Júnior, em seu clássico Formação do Brasil Contemporâneo, circunscreve suas teses ao período colonial que teria deixado sua herança a partir da qual se constituiu o Brasil contemporâneo. Embora afirme que o sentido da colonização é a geração de riquezas por meio da produção de artigos com alto valor comercial direcionados ao mercado internacional, não descura a importância da produção não diretamente a ele relacionada. $\mathrm{O}$ aparecimento de atividades necessárias ao abastecimento do mercado interno é inerente à vida social. Parte disto é realizada nas próprias unidades produtivas. Parte, fora. É o que teria ocorrido em Minas no século XVIII, momento em que aparecem em Minas, mais especificamente em sua parte meridional, atividades produtivas voltadas para o abastecimento das zonas mineradoras. A proximidade do Rio de Janeiro e, mais tarde, o translado da Corte para o Brasil, aprofundaram a vocação sul-mineira no sentido da produção de gêneros de subsistência. Inúmeras são as indicações neste sentido, de relatos de viajantes estrangeiros aos dados colhidos em censos provinciais, relatórios de presidentes, memórias escritas deixadas por personagens insignes da vida social mineira, confirmando o perfil econômico diferenciado da estrutura econômica de variadas regiões de Minas, notadamente do sul (Prado Júnior, 1987, p. 78, 162, 197).

Porém, além de as afirmações de Caio Prado se referirem ao período colonial, em seu trabalho específico sobre história econômica do Brasil, no período referente ao século XIX, quase nenhuma indicação há que enfatize a importância das atividades econômicas não voltadas à exportação. Afinal, para ele, o constitutivo essencial da formação social brasileira era a produção de artigos com alto valor comercial destinados ao mercado europeu. Mesmo quando aborda a questão do renascimento agrícola do século XVIII, está indicando a revitalização da produção de artigos voltados à exportação (Prado Júnior, 1986, p. 79-93).

Nas quase 100 páginas em que analisa a economia brasileira no século XIX, não há qualquer referência à importância da produção voltada à subsistência. Quando analisa os produtos da agricultura brasileira, tem em mente os que se voltam à exportação (Prado Júnior, 1986, p. 157-167). Esta arquitetura é compreensível em função da época em que foi escrito o livro e da perspectiva em que se baseia: o sentido da colonização brasileira, não superado quando da 
separação entre Brasil e Portugal, uma vez que o novo país se inseriu nos quadros de uma nova divisão do trabalho, hegemonizada pela Inglaterra e no interior, agora, de um contexto de avanço do capitalismo internacional.

Celso Furtado passa ao largo de tudo isso. O seu esquema teórico não dá conta de perceber a importância que a economia de abastecimento interno teve no Brasil como um todo e, mais ainda, quando se refere ao caso de Minas Gerais. Para ele, ela é tributária da grande lavoura voltada à exportação e só ganha algum vulto quando aquela entra em crise. Ao se referir à produção de subsistência tem em mira a sua subordinação à grande lavoura, ou à mineração. A ela se ligam os conceitos, por ele utilizados, de comunidades isoladas, atrofiamento da economia monetária, população desarticulada, baixíssima produtividade (Furtado, 1984, p. 85-86).

Quase salta da análise da mineração para a do café. No interregno entre ambas, situa a gestação da economia cafeeira que marcaria o reencontro do país com a prosperidade, por meio da sua reinserção no mercado internacional. Atribui a emergência da cafeicultura a um conjunto de fatores, entre os quais, a acumulação de capital e a experiência adquirida na lida com a produção de subsistência (Furtado, 1984, p. 115).

Nos últimos anos, contudo, uma série de novos trabalhos desenhou um perfil mais poliforme da economia mineira no século XIX. No conjunto, eles sepultaram as visões mais tradicionais e rígidas, enriqueceram as perspectivas de análise e ofereceram dados que permitiram uma interpretação mais rica do que aí teria se passado.

Alcir Lenharo investigou a temática da economia sul-mineira do século XIX, sob a perspectiva do abastecimento de centros urbanos, marcadamente do Rio de Janeiro, articulando-a a uma dimensão política, em que ela constituiu na base para a formação de uma rede de interesses econômicos e políticos que entrelaçaram os objetivos dos moderados da Corte à elite política do sul de Minas, no período regencial.

Aliada à exploração de uma vasta documentação primária, a perspectiva teórica do autor ofereceu dados que auxiliam na superação das visões mais tradicionais e rígidas que entendem a economia de subsistência como tributária da grande lavoura de exportação. Trabalhando num momento em que a ênfase nos estudos regionais indicava a existência de um vasto campo prolífico de estudos; em que o acúmulo de dados empíricos permitia uma visão mais multifacetada da realidade social brasileira; o debate teórico permitia a compreensão de uma relação mais complexa entre produção de subsistência e grande lavoura exportadora, ele constatou o caráter mercantil da produção de subsistência no sul de Minas no século XIX, posterior ao boom do ouro e anterior ao aparecimento da 
cafeicultura, como seu elemento definidor, base para a reprodução social e para as intrincadas relações econômicas e políticas com o Rio de Janeiro (Lenharo, 1979, p. 24-25).

Lenharo nota que, para a conclusão do seu trabalho, além da superação de obstáculos oriundos da dispersão das fontes, ausência de estudos monográficos, foi fundamental a superação de perspectivas teórico-metodológicas que dificultavam a apreensão da produção de subsistência para além da subordinação à lavoura de exportação. Em uma rápida crítica historiográfica mostra as limitações advindas das obras de Roberto Simonsen e Celso Furtado, reconhece a dívida para os trabalhos de Caio Prado Júnior, Kenneth Maxwell, Paul Singer, Jacob Gorender que, em maior ou menor medida, contribuíram para aclarar a especificidade da temática relativa à produção de subsistência, embora com ressalvas sobre pontos específicos (Lenharo, 1979, p. 33-36).

No início dos anos 1980, Roberto Borges Martins iniciou a publicação de uma série estudos sobre a economia e sociedade mineiras do século XIX que, pela riqueza e densidade da argumentação, sepultou de vez as teses principais da antiga historiografia sobre Minas oitocentista, e deu início a um prolífico debate que não pode ser desconhecido pelos interessados no assunto.

Em 1980, defendeu sua tese de doutorado na University Vanderbilt, com o título de Growing in silence: the slave economy of nineteenth-century Minas Gerais, Brasil. Nos anos seguintes, em sua série de artigos publicados em revistas especializadas brasileiras, desenvolveu detalhes e reafirmou suas teses centrais. Baseado em uma ampla compilação de dados, organizados em quadros estatísticos variados, revelou o caráter singular do tipo de economia e da força de trabalho em Minas no século XIX, muito diferente do padrão verificado em outras regiões do Brasil, e que não foi percebido teoricamente pela maior parte dos pesquisadores. $\mathrm{O}$ resultado é a necessidade de uma reavaliação não só da interpretação da economia e sociedade mineiras, senão da própria elaboração teórica muito afeita em desconhecer a relação do trabalho escravo com outra configuração econômica que não se enquadre na produção voltada à exportação, além de apressada em definir a realidade de Minas Gerais pós-ciclo da mineração como decadente, à espera de um produto capaz de reinserí-la nos mecanismos da economia internacional: o café.

Havia uma tendência nas abordagens tradicionais no sentido de caracterizar a província como área perdedora de escravos, concentrados na época da mineração.Só com a emergência do café teria o processo sido revertido. Além de exportar escravos para outras províncias, teria havido uma migração interna de escravos para as áreas de cafeicultura (Martins, 1983, p. 181-182).

Martins considera que por trás desta visão, está o quadro conceitual de uma economia exportadora tida como baluarte da prosperidade (única capaz de 
sustentá-la) e concentradora da força de trabalho escrava. As demais atividades não se constituiriam em centro econômico dinâmico, meros figurantes incapazes dar suporte à prosperidade e de manter um grande plantel de escravos, validando a concepção de uma relação automática entre escravidão - riqueza e economia exportadora.

Para Martins, Minas manteve um grande plantel de escravos ao longo do século XIX, garantido pelas compras contínuas de escravos. Sua economia estava organizada sem ligação com o mercado internacional, ao contrário do que advogavam as teses tradicionais. Aspecto fundamental da tese: o suporte econômico estava em sua economia não exportadora, absolutamente desligada do mercado internacional e da grande lavoura.

O número de escravos empregados na mineração era irrisório, e a cafeicultura só se tornou considerável em meados da segunda metade do século, não se justificando a afirmação, aceita com alto grau de consenso, da transferência interna de escravos para áreas dedicadas à produção de café (Martins, 1983, p. 183).

Em 1872, cerca de $95 \%$ da população escrava estavam empregadas em atividades que não a mineração e cafeicultura. Eram cerca de 360 mil escravos, população maior que a de qualquer outra província. Na realidade, Minas foi grande importadora de escravos, considerando-se que o crescimento vegetativo da população escrava era negativo e que, no período anterior à cessação do tráfico, cerca de $30 \%$ do total de escravos importados pelo Brasil, a ela eram destinados (Martins, 1983, p. 184-187). O apego à escravidão foi até o fim.

Em contraste com os conceitos tradicionais, escravidão-riqueza-lavoura exportadora, interligados, Martins apresenta o caso sui generis de Minas: produção de subsistência com baixo grau de mercantilização-escravidão. Afirma ele:

O grosso da economia de Minas no século XIX, onde a vasta maioria dos escravos estava empregada, não se compunha de plantation nem era orientado para exportações. Isolamento de mercados externos à província, diversificação e autosuficiência eram suas características principais. Minas tinha um dos mais baixos níveis de exportações per capita do país. A grande lavoura exportadora permaneceu confinada a uma pequena área e o cerne da economia provincial consistia de unidades agrícolas diversificadas internamente - produzindo para o seu próprio sustento e vendendo os excedentes em eventuais mercados locais e regionais (Martins, 1983, p. 209).

Os desafios às teses tradicionais são evidentes. Todos os participantes do debate o reconheceram (Slenes, 1985, p. 5, 9; Cano, 2002, p. 35; Libby, p. 19-20). A tese de Martins, entretanto, esbarra num obstáculo extremamente problemático. Se a economia mineira possuía um baixo grau de mercantilização, fica muito difícil explicar a manutenção do grande plantel escravista que ele afirma ter 
existido e que nenhum dos seus críticos negou. O escravo é uma mercadoria cara. Depois do fim do tráfico tornou-se quase proibitiva a sua posse. Como conciliar a concepção da existência de um grande plantel escravista com a do baixo grau de mercantilização da economia? Problema que não passou despercebido da maioria dos seus críticos.

A explicação sustentada por Martins conjuga a manutenção da escravidão com a grande quantidade de terras disponíveis em Minas, facilmente apropriadas, constituindo-se num fator de atração para uma multidão de pessoas livres com pouca ou nenhuma posse, resistentes ao trabalho fixo ao lado do escravo, ou sob a tutela do fazendeiro. Sem poder contar com o trabalhador livre, no contexto de uma situação caracterizada pela ausência de fechamento de recursos, aos proprietários não restou alternativa senão a posse de escravo e a garantia do trabalho compulsório. Martins chama a essa conjugação de variáveis de fator Wakefield, adaptado às condições de uma região não dominada pela grande lavoura exportadora.

A mais séria crítica às posições de Martins veio de Robert Slenes. Ele questiona o cerne da sua tese. Embora aceite que o caso de Minas seja singular e force revisões de teses (Slenes, 1985, p. 12, 30), e que Martins demonstra de forma convincente a relação entre economia e apego à escravidão, recusa as afirmações de que a economia mineira possuía baixo grau de mercantilização e do seu suposto desligamento em relação à economia exportadora. A idéia de uma economia pouco afeita ao comércio e às redes mercantis em geral não dá suporte para explicar a presença do grande plantel escravista. $\mathrm{O}$ apego de Minas à escravidão não se deveu ao fator Wakefield, que sem dúvida jogou um papel no processo, mas é insuficiente para o esclarecimento dos seus verdadeiros motivos (Slenes, 1985, p. 21).

Para Slenes (1985), na realidade Minas fazia parte de um grande complexo comercial (p. 9, 39-63). Se a sua produção não se dirigia diretamente para o exterior, por meio da plantation, era, sim, parte de uma rede comercial que possuía nela o seu centro dinâmico, trabalhando para abastecê-la e às cidades que, de alguma forma, com ela estabeleciam relações (p. 59).

A grande discordância com Martins está na interpretação de Minas como uma economia não pouco comercial e auto-suficiente como fora por ele afirmado. A ligação com o setor exportador teria sido o seu centro dinâmico, com grande impacto sobre os demais setores voltados para o cultivo de produtos de subsistência.Tratava-se de um complexo comercial que criou as condições para a manutenção do plantel escravista considerável da província.

Essa constatação, aliada a outros elementos, como o fator Wakefield, o alto custo do transporte no litoral e a inviabilização das importações de alimentos, 
o preço acessível do escravo até 1850, antes do fim do tráfico, em conjunto, atuaram para impedir a formação de um mercado de trabalho livre, capaz de se viabilizar como alternativa ao trabalho escravo. Daí, forçosamente, a opção dos que possuíam recursos pela compra de escravos (enquanto isso foi possível) ou mantê-los, após o fim do tráfico e das leis que, aos poucos, foram cerceando o tráfico interno.

Numa outra vertente, com uma argumentação diferente da de Slenes, Wilson Cano questiona a explicação de Martins para a manutenção do grande plantel de escravos em Minas, mas aceitando a afirmação do baixo grau de mercantilização da sua economia e a atuação do fator Wakefield. Aponta uma série de contradições em sua obra e indica que a explicação para o número expressivo de escravos não tem, também, relação com a economia mercantilizada como advoga Slenes. É partidário de Martins na questão da economia mineira com baixo grau de mercantilização e aí se encontra a solução para a questão da presença do grande plantel escravista. Numa organização econômica assim configurada, o grau de exploração da força de trabalho é baixo, permitindo o afloramento das condições sociais para uma reprodução natural positiva dos escravos, condição ainda mais importante após o fim do tráfico de escravos, mas, nem por isso, ausente na fase anterior (Cano, 2002, p. 43).

O autor, no pós-escrito, cita o seu trabalho em parceria com Luna e a conclusão a que ambos chegaram:

Dado que, se realmente ela era pouco mercantilizada, não restava outra hipótese senão a do rebaixamento da taxa de exploração, do relaxamento da repressão e dos costumes, e, conseqüentemente, de uma alta taxa de reprodução natural (Cano, 2002, p. 43).

A tese de ambos requer muita pesquisa empírica sobre demografia em Minas, que ainda está em fase inicial, para verificar o grau de africanização da população escrava, a sua composição etária e a dimensão da presença da família escrava.

Outro importante trabalho sobre a questão é o de Douglas Cole Libby, que entende não ser mais possível sustentar as teses tradicionais sobre Minas oitocentista, no estágio atual das pesquisas (Libby, 1988, p. 14).

O autor se alinha ao lado dos que advogam o caráter mercantil da economia mineira como base de sustentação para o crescimento populacional como um todo, e para a população de escravos especificamente. Embora reconheça a função importante desempenhada na revisão da literatura histórica sobre Minas no século XIX pelos trabalhos de Roberto e Amílcar Martins, não comunga das suas teses sobre os fatores responsáveis pela manutenção do grande plantel de escravos aí verificado. 
O autor utiliza muitos dados quantitativos sobre a economia e sociedade mineiras, disponibilizados pelos mapas de população de Minas Gerais nos anos de 1831-1832 e 1838-1840, por dados extraídos das respostas dadas por municípios a solicitações do governo provincial na década de 1850, e pelo censo de 1872 . Várias tabelas, gráficos e quadros sobre questões relativas à população, ocupação, posse de escravos e terra, compõem um referencial rico para uma análise mais profunda e detalhada, que possibilita uma compreensão mais próxima da realidade complexa que foi a economia e sociedade mineiras no século XIX.

Não dependente do café, não tendo na exploração do ouro o seu centro dinâmico, a economia escravista de Minas viveu da produção mercantil de subsistência, aliada a um setor, objeto que ocupa o centro da reflexão do autor no trabalho em questão: a presença significativa em Minas de uma indústria de transformação de matérias-primas em artigos acabados, numa gama que ia da "produção doméstica de fios e panos, de oficinas artesanais de todo tipo, de pequenas e médias manufaturas e até de verdadeiras fábricas de ouro e tecidos" (Libby, 1988, p. 14).

Além de uma estrutura produtiva diversificada, a massa de trabalhadores que a ela se dedica se constitui de uma multidão de tipos que exige análise cuidadosa para evitar generalizações indevidas. Pelos dados coligidos na pesquisa, referente aos anos 1831-1840, cerca de dois terços dos lares mineiros não possuíam escravos. Como sobreviviam, a que se dedicavam? A posse de escravos, pequena ou grande, é realidade para um terço da população. As grandes posses são exceções. Dos 6.583 domicílios analisados pelo autor, apenas 163 têm mais de 30 escravos; desses, seis possuem mais de 100 escravos; e 42 possuem entre 50 a 100 escravos (Libby, 1988, p. 97-109).

Ao lado do trabalho escravo, há uma grande massa de trabalhadores livres que não pode e não deve ser ignorada. Desde os anos 70 do século $\mathrm{XX}$, a pesquisa vem dando ênfase a essa categoria, fazendo aparecer o quadro de uma configuração social, cultural e econômica que foi descurado nas pesquisas mais antigas. Pelo número nada desprezível da sua presença em Minas, é possível que tenha jogado um importante papel social e econômico que as pesquisas estão tentando elucidar. Não está ainda claro o quantum da sua participação na economia mercantil mineira e as variadas formas de trabalho a que se dedicava.

Libby acredita que a existência de um grande número de escravos, ao lado do enorme contingente de trabalhadores livres, não deixou de ter conseqüências para a configuração de um certo tipo de relação entre esses e os proprietários. Anteriormente, Roberto Martins afirmara que as duas categorias de trabalhadores não existiram lado a lado como se nenhuma conseqüência daí derivasse. Ele relaciona a manutenção da escravidão à condição de fronteira aberta de Minas com 
relativa facilidade de acesso à terra aos trabalhadores livres. Ao mostrar o grande número de pessoas livres trabalhando em atividades de transformação, o autor evidencia o processo, não inteiramente concluído no século XIX, da sua proletarização, obstado pela conjugação do trabalho em pequenas propriedades, em que elas detinham certo grau de autonomia, como pode ser verificado nas pequenas indústrias de transformação. Trabalhadores sazonais, muitos mantinham a pequena propriedade, à qual se dedicavam para retirar a sua subsistência, complementada com o trabalho assalariado parcial. Arranjo mantido graças à presença do trabalho escravo que os aliviava de uma pressão social e política, claramente posta em prática a partir da agudização da crise do escravismo, quando os discursos dos proprietários escravistas, necessitados de trabalhadores, clamam ao governo para promover a proletarização forçada dessa massa de trabalhadores livres tidos como indisciplinados e preguiçosos (Libby, 1988, p. 346-347).

Esta rápida incursão pela historiografia sobre a economia e sociedade mineiras do século XIX teve a intenção de mostrar o avanço nas pesquisas sobre a sua complexa realidade que, ao ser esclarecida, além de romper definitivamente com as visões mais rígidas e simplificadas sobre o assunto, aponta para a necessidade de flexibilizar e enriquecer modelos teóricos que relacionam trabalho escravo com grande produção exportadora, que não deixa, absolutamente, de ser uma realidade, mas dela fogem ao tentar aprisioná-la nesse crisol.

Hoje, espalhadas por várias instituições, multidões de pesquisadores se debruçam sobre dados demográficos e econômicos mais localizados que, ao final, permitem um conhecimento mais profundo da vida econômica e social de Minas Gerais no século XIX.

\section{Sociedade e economia no sul de Minas no século XIX}

Kenneth Maxwell, citando dados de Dauril Alden, e baseado em informações atribuídas a Cláudio Manuel da Costa, informa que entre os anos de 1772-1782, a população da capitania de Minas Gerais era estimada 319769 habitantes. Era a maior população no conjunto da colônia, totalizando um percentual de 20,5\%. Maior que a população da Bahia, segunda colocada, com 288 848, cerca de 18,5\% do total, e de Pernambuco, com 239 713, 15,4\%, em terceiro lugar (Maxwell, 1977, p. 299).

Naquele momento, a conjuntura econômica era marcada pela crise da mineração, revelada pelo decréscimo do percentual do quinto arrecadado em todos os anos subseqüentes (Maxwell, 1977, p. 286-287). Os dados disponíveis indicam que, apesar da crise no setor, o crescimento da população da capitania foi uma constante, significando que não implicou a sua decadência econômica. Estava em curso em Minas uma notável transformação da sua base econômica. De 362.847 
habitantes em 1786, a população passou a 518.985 em 1823. Crescimento expressivo de 156.138 pessoas (Revista do Arquivo Público Mineiro, 1899, p. 294295).

Guilherme, Barão de Eschwege, em uma série de dados sobre a província, afirma que a população de Minas em 1821 era de 514108 habitantes (Revista..., 1899, p. 744).

Em uma série de dados estatísticos colhidos em fontes diversas e sobre épocas diferentes, Cunha Matos estima a população da província em $1831 \mathrm{em}$ cerca de 600.000 pessoas (Matos, 1981, p. 64).

Os dados coligidos por Libby mostram o quadro da população de Minas em dois momentos mais avançados do século XIX. Tabulando dados de censos paroquiais dos anos 1950, solicitados pelo governo provincial, indica um total de 961.582 habitantes. O censo de 1872, que o autor utiliza para comparação, indica uma população de 2.039.735 habitantes (Libby, 1988, p. 365). É a maior população do Brasil, condição mantida em todo século XIX. O censo de 1890 indicou uma população de 3.184.099 habitantes. A título de comparação, em referência às duas últimas datas, a Bahia se situava em segundo lugar, com 1.379.616 e 2.117.956 habitantes. Rio de Janeiro, 1.057 .696 e 1.399.535. São Paulo, 837.354 e 1.384.753. Pernambuco, 841.539 e $1.030 .224 .^{3}$

A pujança econômica e populacional de Minas lhe deu as condições para exibir a maior representação parlamentar no império. Afonso de E. Taunay traz uma série de dados sobre a representação parlamentar no império em diversos momentos. A deputação às cortes de Lisboa, em 1820, era constituída de 68 deputados, dos quais 12 de Minas, 8 de São Paulo, 7 do Rio de Janeiro, e as demais circunscrições com números bem abaixo. A constituinte de 1823, com 89 deputados, era composta por 20 deputados de Minas, 13 de Pernambuco, 11 da Bahia, 9 de São Paulo e 8 do Rio. A primeira legislatura imperial, reunida em 1826, era composta por 20 deputados de Minas, 13 de Pernambuco e Bahia, 9 de São Paulo, 8 do Ceará, e as demais províncias com números bem aquém. Em novembro de 1889, o senado imperial era composto por 235 membros, sendo 45 de Minas, 28 da Bahia, 25 do Rio, 23 de Pernambuco, 19 do Ceará, 16 de São Paulo, e as demais províncias com uma representação bem inferior (Taunay, 1998, p. 23, 47-49).

Diversos trabalhos demonstram a diminuição do percentual da população escrava no conjunto da população de Minas ao longo do século XIX, a despeito do seu crescimento em números absolutos.

(3) Dados dos Censos de 1872 e 1890.

Economia e Sociedade, Campinas, v. 16, n. 2 (30), p. 259-287, ago. 2007. 
Em 1786, constituía 47,9\%; 1805, 46,4\%; 1808, 34,3\%; 1821, 33,3\%; 1823, 27\% (Revista..., 1899, p. 294-295).

Dados trabalhados por Libby, mostram que no decênio 1831-40, a população escrava de Minas constituía 31\% do total. Em 1872, havia caído para 22,19\% (Libby, 1988, p. 368).

Esses dados corroboram as conclusões de Clotilde Andrade Paiva e Tarcísio Rodrigues Botelho, que calculam o percentual da população escrava em 34,15\% entre 1833-35, em 30,46\% em 1855, e em 19\% em 1872 (Paiva; Botelho, 1995, p. 98).

O plantel escravista de Minas, no entanto, não cessou de crescer ao longo do século XIX e, em números absolutos, constituía o maior entre as províncias brasileiras, como expresso pelos dados coligidos por Roberto Borges Martins, comparando o número de escravos das diversas províncias em dois anos polarizados no tempo, 1819 e 1872. Minas possuía, respectivamente, 168.543 e 381.893 escravos; enquanto o Rio de Janeiro, 91.070 e 306.425; São Paulo, 77.667 e 156.612; a Bahia, 147.263 e 167.824. O influxo do crescimento para Minas foi de 1,53\% ao ano; para o Rio de Janeiro, 2,31\%; São Paulo, 1,28\%; Bahia, 0,24\% (Martins, 1983, p.188).

Emília Viotti da Costa exibe dados sobre Minas, Rio e São Paulo que permitem corroborar as afirmações acima. Segundo os dados por ela disponibilizados, São Paulo possuía uma população escrava de 117.731 em 1854, de 156.612 em 1872, de 174.622 em 1883, e de 160.665 em 1886. O Rio de Janeiro, de cerca de 300.000 em 1873 para 160.000 em 1887. Em Minas, de 370.000 em 1872, de 226.000 em 1885, e de 191.000 em 1887 (Costa, 1989, p. 229-231).

O cerceamento ao tráfico interprovincial promovido pela legislação das três maiores províncias importadoras de escravos, Minas, Rio de Janeiro e São Paulo, no início dos anos 1980 (Costa, p. 232-234; Martins, 1983, p. 205), aliado aos efeitos da promulgação das leis do Ventre-livre e dos Sexagenários, a despeito do seu resultado muito aquém do esperado, fizeram diminuir sensivelmente o percentual da população escrava em geral.

Todos esses dados demonstram o apego à escravidão das três mais importantes províncias brasileiras. As ações governamentais no sentido de dificultar a alimentação do abastecimento do mercado de escravos, por meio do tráfico interprovincial, via aumento na taxação de impostos sobre a entrada de escravos nas referidas províncias, suscitaram reações resolutas da parte dos proprietários da grande lavoura. Não foi sem dificuldades que os governos provinciais de Minas, Rio e São Paulo conseguiram fazer aprovar as leis cerceadoras do tráfico interno. Foi em meio à conjuntura de esgarçamento da 
perspectiva de continuidade da escravidão, na década de 1980, em vista do intenso movimento social em prol do abolicionismo, quer no parlamento, quer na sociedade e, sobretudo, nas senzalas, e em meio à busca de alternativas para o trabalho escravo, promovida de forma mais enfática pela província de São Paulo via imigração subsidiada, que as classes detentoras de escravos se viram forçadas a ceder, a despeito das inúmeras tergiversações.

Em Minas, constata-se uma sensível diminuição do braço escravo em diversas regiões da província após 1872. Mas isto não se verifica em duas regiões: cresce na Zona da Mata, então na pujança da cafeicultura, e se mantém no Sul, em que ela ainda não é significativa.

Martins, trabalhando com dados referentes às regiões que compunham a província de Minas, constata a presença de percentual exíguo de escravos na população do Alto Parnaíba, Oeste, Triângulo, São Francisco-Montes Claros, Paracatu, Jequitinhonha-Mucuri-Doce, desde o início dos anos 1980. Mais significativos são os números das regiões Metalúrgica-Mantiqueira, Mata e Sul.

Na Metalúrgica-Mantiqueira, de 24,9\% em 1873, caiu para $17,3 \%$ em 1886. Já o sul de Minas manteve, praticamente, o mesmo percentual desde 1873, $21,3 \%$ para $21,4 \%$ em 1886. Muito expressivo foi o que ocorreu na zona da Mata, a grande região cafeeira de Minas, onde o percentual subiu de 26,3\% em 1873 para 30,9\% em 1880, para 35,8\% em 1884, e para 36,4\% em 1886 (Martins, 1983, p. 198). Um percentual muito significativo em vista do crepúsculo da escravidão no Brasil.

O que explica o comportamento do sistema escravista em Minas, sobretudo nas regiões da Zona da Mata e do Sul?

Aqui entramos no fulcro do grande debate sobre o caráter da economia mineira. $\mathrm{O}$ que lhe permitiu dar suporte à maior população escrava do Brasil?

Como já foi analisado atrás, Roberto Martins e Amílcar Martins argumentam que a explicação para a enorme população escrava de Minas, e o seu apego a ela até o fim, não pode se basear no pressuposto do caráter comercial da sua economia, quase toda ela com baixo nível de mercantilização, fora do circuito da plantation. São as condições de fronteira aberta da situação fundiária existente em Minas, aliada à presença de um expressivo campesinato, os responsáveis pela utilização do escravo no trabalho. Sem a possibilidade de utilizar os trabalhadores livres, não restava alternativa aos proprietários que não a utilização do braço cativo.

Os críticos da tese central dos Martins indicam a aporia dessa concepção: a impossibilidade de manter escravos prescindindo dos recursos para a sua aquisição e manutenção, dificilmente imagináveis fora de uma economia com relativo grau de mercantilização. 
Os dados disponíveis apontam noutra direção. Trabalhos de pesquisa que vão de Caio Prado, passando por Alcir Lenharo, e chegando a Robert Slenes evidencia, que a economia mineira tinha forte inserção no circuito comercial interprovincial, sobretudo com o Rio de Janeiro.

O caráter mercantil da produção destinada ao consumo em Minas data do século XVIII. A exploração do ouro ocorreu ao mesmo tempo em que crescia a produção de artigos destinados ao consumo da população dedicada à mineração. Essa foi a característica mais forte da comarca do Rio das Mortes, em que uma expressiva produção de ouro se aliava à de produtos voltados ao abastecimento interno.

Quando a exploração do ouro foi chegando ao fim, em quase todo o território da província, sobretudo no sul, a feição agrícola, não da grande lavoura, mas daquela devotada à produção de gêneros de subsistência, estava consolidada. O seu aparecimento se deveu à necessidade de abastecimento que as áreas produtoras de ouro exibiam, já no século XVIII. No século XIX, ela voltou-se, sobretudo, ao abastecimento da Corte no Rio de Janeiro.

A produção para subsistência em Minas foi uma necessidade. Uma região interiorana, com condições naturais excelentes para o plantio e para a pecuária, um mercado regional em expansão, mais tarde as demandas oriundas da Corte, não poderiam deixar de se constituir em atrativos para alavancar a sua prosperidade.

O sul de Minas era grande produtor de milho, arroz, feijão, fumo, gado, porcos, queijos, carne salgada. Isso é evidenciado com muita clareza quando se examina, ao longo de pontos extremos na escola temporal, 1821 e 1884, a produção por municípios no mapa de Von Eschwege (Eschwege, 1899, p. 737$752)^{4}$ e no Almanak Sul-Mineiro de Bernardo Saturnino da Veiga. ${ }^{5}$ Ambos indicam que a variação na produção não foi muito significativa: desfilam os mesmos produtos, com a mesma finalidade, à exceção do café, que na década de 80 emerge como produto importante.

Dados colhidos nos relatos de viajantes estrangeiros que estiveram em Minas; dados colhidos nas recebedorias localizadas nas fronteiras com Rio de Janeiro e São Paulo; relatórios dos presidentes da província indicam que a economia mineira estava inserida no circuito comercial regional e interprovincial, embora não seja fácil dimensionar o grau e a profundidade desta inserção. As diferenças regionais e sociais em relação ao menor ou maior envolvimento com a

(4) O autor foi um estudioso da economia e da movimentação demográfica de Minas. Os seus mapas econômicos e de população, bem como sua reflexão, servem como um material básico para os interessados na realidade socioeconômica de Minas no início do século XIX.

(5) O autor fez uma grande pesquisa em todas os municípios do extremo sul de Minas. É uma importante referência de dados de toda espécie sobre a região. 
atividade comercial são consideráveis. Nem todas as regiões e nem todas as pessoas se dedicavam a alguma forma de atividade produtiva direcionada ao mercado na mesma proporção. Entre os cerca de dois terços da população mineira não proprietários de escravos, certamente não eram poucos os que com ele se relacionavam de forma muito esporádica.

Os centros mais dinâmicos das atividades produtivas estavam ligados a áreas com alto ou médio nível de ligação com o comércio. Significativamente, essas eram as áreas com maior contingente de escravos. Se nelas se traçar um corte social, em que estejam relacionados conceitos como posse de escravos e condição socioeconômica dos proprietários, verifica-se uma grande concentração da posse nas mãos de pessoas com forte ligação com a comercialização de seus produtos.

O contingente de cerca de um terço da população de Minas, proprietário de escravos, que não deve ser concebido como um grupo homogêneo, pode ser agrupado em faixas que elucidam a desconcentração da propriedade de escravos, quando se considera o número de possuidores, e a enorme concentração da posse de escravos quando se focaliza o plantel detido por cada faixa.

As conclusões de Libby mostram que em Minas Gerais, a despeito das diversidades regionais, cerca de $3 \%$ da população de proprietários de escravos detêm $20 \%$ do total de escravos, com posses que podem ser consideradas grandes (acima de 30 escravos). Se a esse número se agregar os percentuais de proprietários de posses com 16 a 20 escravos e com 21 a 30 escravos, chega-se à seguinte conclusão: $9 \%$ do número de proprietários detêm 38\% do número total de escravos. Por outro lado, na base oposta, aquela com proprietários com posses menores, constata-se que $23 \%$ dos proprietários, com apenas um escravo, detêm cerca de $4 \%$ do total de escravos. Na faixa seguinte estão os proprietários com dois escravos: cerca de $16 \%$ do total de proprietários, totalizando cerca de $6 \%$ do número de escravos. Ou seja, $42 \%$ dos proprietários de escravos, no total, possuem cerca de $10 \%$ dos escravos.

São proprietários de escravos, mas não podem ser colocados como fazendo parte de uma categoria homogênea. A sua forma de inserção no mercado não é a mesma.

As minuciosas pesquisas conduzidas por Clotilde Paiva, centradas nas análises das listas nominativas de 1831-1832, evidenciam um elemento que clareia ainda mais a questão. É a importância do grupo de comerciantes como categoria sobressalente na posse de escravos. Não para trabalhar no comércio, mas como forma de diversificação das suas atividades. Eles estão presentes em maior número nas regiões de maior dinamismo econômico, em que a população é maior e mais concentrado o número de escravos. $\mathrm{O}$ que não constitui qualquer problema. 
Significativa, porém, é a confirmação do papel de intermediário que os grandes comerciantes de Minas vão assumindo, indicando um domínio sobre as atividades produtivas e comerciais de variadas camadas sociais. Isso nada tem de excepcional dada a dinâmica do processo nas economias mercantis, em que os produtores não vendem os seus próprios produtos, a não ser em pequena escala e em espaços contíguos ao seu local de moradia. Quando se focaliza a relação comercial forte de Minas com o Rio de Janeiro, em que a distância é grande e as estradas são muito precárias, não é difícil entender o surgimento de agentes comerciais articulados com várias regiões e produtores, no sentido de intermediar a comercialização de seus produtos.

Alcir Lenharo já havia afirmado isso em referência à existência de grandes fazendas no sul de Minas como locais de invernada de gado, posteriormente conduzidos ao Rio de Janeiro (Lenharo, 1979, p. 37).

Clotilde constata que, em Minas Gerais, mais de três quartos dos envolvidos com a circulação de mercadorias eram originários das regiões com alto índice de inserção comercial, em que a presença de tropas dedicadas à comercialização constituía $76,9 \%$ do total da província. Somados todos os domicílios com dedicação ao comércio, 56,6\% se constituíam de unidades escravistas. Portanto, mais de $80 \%$ acima do número de domicílios escravistas em geral, que em Minas, perfaziam um total de cerca de $30 \%$ da população. Os domicílios com comerciantes representavam cerca de $8,9 \%$ do total de domicílios de Minas e cerca de 16,2\% das unidades escravistas em geral, em que o número de escravos era expressivo, sobretudo nas unidades maiores, em que o comércio era uma entre várias atividades do proprietário (Paiva; Godoy, 2002).

As pesquisas e os dados disponíveis permitem algumas conclusões amplamente aceitas pela comunidade acadêmica sobre a realidade socioeconômica de Minas no século XIX:

(1) Embora de forma diferenciada em suas regiões constitutivas, é difícil negar a inserção comercial de Minas num circuito que abrange desde a ligação intraprovincial, com uma variedade de pontos e rotas, até a forte relação com o Rio de Janeiro.

(2) Os centros de maior dinamismo comercial (Zona da Mata, sul de Minas, Zona Mineradora) exercem efeito agregador e dominador, no sentido de centros de referência para os quais são direcionados os excedentes produzidos, sobre os demais.

(3) A produção de artigos com grande valor comercial, como o café e minerais preciosos (em alta na segunda metade do século), em menor escala pode se considerar também o fumo, produzido em quase todas as regiões de Minas, com destaque para o sul, exercem efeito multiplicador sobre os demais setores da 
economia, aumentando a demanda por produtos de subsistência, como muito bem indicou Robert Slenes para o caso do café e da produção de minerais preciosos.

(4) Não é desprezível o peso de outros setores produtivos na dinâmica geral da economia. Na verdade, a economia mineira é bastante diversificada, cobrindo uma gama de produtos que vai da produção de ouro, café, artigos de subsistência em geral, algodão, fumo e produtos manufaturados, como a extensa rede de produção doméstica de tecidos de algodão espalhada por todo o Estado de Minas, até a produção de artigos mais sofisticados como, por exemplo, a produção de chapéu em São Gonçalo, termo da Vila de Campanha, sul de Minas, numa fábrica com 32 empregados, estimada em 15 a 16 mil unidades/ano. O trabalho de Libby, nesse sentido, é bastante expressivo na medida em que revela um setor dinâmico da economia mineira quase sempre desconsiderado. Ilustrativo, também, a respeito da diversidade da produção mineira, são os relatórios dos presidentes da província, em que exaustivamente é relacionada a variada produção de Minas e a sua dimensão mercantil. ${ }^{6}$

(5) Uma expressiva parcela da população de Minas, cerca de dois terços, não faz uso do trabalho escravo. A sua inserção no mercado é muito frágil. $\mathrm{O}$ restante da população, parcela minoritária, a utiliza. Há grande diversidade interna nesse grupo. A maior parte dos proprietários de escravos tem posse muito pequena. A posse de escravos está concentrada em setores diminutos de médios e grandes proprietários, com forte inserção mercantil, indicando a localização das fontes de renda para a aquisição e manutenção do plantel escravista. Esses setores se apegaram à escravidão até o fim, a despeito das leis abolicionistas e do encarecimento do preço do escravo verificado após a aprovação da lei Eusébio de Queirós e da onerosa taxação da entrada de escravos de outras províncias no início dos anos 1980.

\section{A reprodução do trabalho como elemento fundamental para a reprodução do sistema econômico}

Se a existência de um setor produtivo com forte inserção comercial, portanto, gerador de renda, é um componente essencial para se pensar a reprodução do sistema econômico, que tem na utilização do trabalho escravo um decisivo eixo sustentador, a ser reproduzido necessariamente, é suficiente?

$\mathrm{Na}$ realidade, elementos não econômicos da vida social devem ser enfatizados para a compreensão mais profunda da reprodução da força de trabalho. Não se trata de criar uma dicotomia entre uma e outra instância, como se na vida

(6) Vale a pena conferir os relatórios de presidentes, entre outros, o de Quintiliano José da Silva, de 1845, e o de 1854 de Francisco Diogo Vasconcelos. São longos e traçam um panorama sugestivo da diversificação econômica de Minas.

Economia e Sociedade, Campinas, v. 16, n. 2 (30), p. 259-287, ago. 2007. 
real elas estivessem presentes de forma estanque ou fosse fácil discriminá-las facilmente. Os pontos que ligam os diversos componentes da vida social, ou melhor, as formas e as circunstâncias que os articulam não são passíveis de ser estabelecidos rigidamente. A vida social é uma síntese de múltiplas determinações não dedutíveis por leis apriorísticas de qualquer natureza.

Ao se afirmar, portanto, que elementos não econômicos devem ser enfatizados para a compreensão da vida social, quer se evitar dois extremos: a concepção de que a dinâmica econômica é determinante dos processos sociais em geral, e a negação da existência de instâncias ou dinâmicas com especificidades próprias, que, se por um lado, não são tributárias daquela, por outro, estão com ela em constante interação.

Portanto, se não se pode pensar a dimensão econômica como suficiente para prover a reprodução do sistema econômico, por meio da reprodução de um de seus baluartes mais importantes, o trabalho, sem os seus suportes o pensamento descamba numa aporia. Trata-se de amarrar os pontos que articulam as relações entre as várias esferas da vida social, num dado momento e local concretos, permitindo um entendimento mais substancial dos processos sociais.

Embora escravista em seu setor mais dinâmico, não é possível desconsiderar que a expressiva parcela de dois terços da população, não possuidora de escravos, nada tenha a ver com a configuração do trabalho da forma como ele se cristalizou em Minas.

Roberto Martins avança a tese da estreita relação entre uso do trabalho escravo em Minas como uma necessidade sentida pelos proprietários em função da inexistência de outras formas de trabalho disponíveis, uma vez que as pessoas livres podiam contar com a fronteira aberta em toda província para ter acesso à terra, mesmo que de forma precária. O fácil acesso à terra impediu a constituição de um mercado de trabalho livre, e se tornou a base para a formação de um amplo estrato camponês que produzia para o auto-sustento, esporadicamente ligado ao mercado (Slenes, 1985, p. 7).

Já são por demais conhecidas as referências desdenhosas à mentalidade e às formas de ação do homem livre, avesso ao trabalho disciplinado, chamado de preguiçoso pelos contemporâneos. Daí o clamor generalizado de proprietários e políticos pela adoção por parte do Estado de uma legislação capaz de coagir ao trabalho essa massa enorme de pessoas.

$\mathrm{O}$ acesso à propriedade dificulta a proletarização. Mais complicado ainda é pensar o trabalho numa sociedade escravista que o reduz à condição ignominiosa de ocupação desprezível. Numa sociedade escravista o trabalho é o ônus do escravo. 
O fácil acesso à terra, a possibilidade de assalariamento parcial, sazonal, a capacidade de produzir para o autoconsumo e o desprezo pelo trabalho sistemático se conjugaram para obstaculizar a transformação da massa de pessoas livres em assalariados.

Douglas Cole Libby mostra a existência de uma configuração econômica composta de setores diversos que abarcava desde a produção de artigos de subsistência para o consumo e para o mercado até o manufatureiro, que não pode contar com uma massa trabalhadora efetivamente assalariada. O processo de assalariamento foi incompleto (Libby, 1988, p. 361). Só ocasionalmente essa massa de trabalhadores livres se empregava para responder às necessidades de subsistência não supridas pelo seu trabalho autônomo. A maior parte do trabalho nas unidades produtivas, sobretudo naquelas que possuíam alguma inserção comercial, era realizada pelos escravos. Isso teria permitido o estabelecimento de uma relação mais tranqüila entre proprietários e homens livres (Libby, 1988, p. 363). O autor inverte o foco ao analisar a relação entre o trabalho escravo e livre. Não é raro analisar esse sob a perspectiva do outro: homens livres na ordem escravocrata. Roberto Martins explica a permanência da escravidão por meio do fator wakefield. Segundo Libby, foi a presença do trabalho escravo em Minas, responsável pela realização de grande parte das atividades produtivas voltadas quer ao consumo quer ao mercado nas grandes, médias e até pequenas propriedades, que assegurou a relativa convivência pacífica entre proprietários e homens livres, pela ausência de pressões sociais e legais sistemáticas pela sua proletarização.

De certa forma, trabalhar com essa questão é navegar em águas turvas, por causa da ausência de dados e de estudos em série, o que conduz as afirmações para muito próximo da especulação. Mas há alguns dados que permitem abrir uma clareira no assunto.

Como explicar a gritaria geral dos proprietários, articulistas de jornais, discursos de parlamentares, observações de presidentes da província, sobre $a$ natural inapetência ao trabalho, clamando pela edição de leis capazes de coibir a vagabundagem dos elementos livres da população diante da falta de braços sentida mais e mais profundamente à proporção em que se anuncia o término da escravidão no país? Esses estereótipos se tornaram senso comum na concepção de políticos e proprietários de terra.

Os lavradores de Baependy, sul de Minas, representados no Congresso Agrícola de 1878 no Rio de Janeiro, assim se expressam sobre os trabalhadores livres:

... e que neste triste estado pouco ou nada trabalham, porque habituaram-se ao pouco e mesmo à miséria, e porque, imersos na ignorância, não consideram o trabalho sob o seu verdadeiro aspecto - como uma lei da natureza humana e uma necessidade social (Congresso Agrícola, 1988, p. 55). 
A comissão nomeada pelos lavradores de São Paulo ao Congresso segue na mesma linha dos de Minas:

Actualmente os nacionais (trabalhadores) auxiliam a lavoura em diminuta escala. Com efeito, a indolência tanto nos hábitos dos colonos nacionais e por tal motivo são elles refractários ao trabalho systematisado, que em número muito limitado prestam-se à locação regular de seus serviços em bem da exploração agrícola (Congresso Agrícola, 1988, p. 75).

A análise dos documentos do Congresso, tanto ao refletir opiniões pessoais quanto coletivas, evidencia, na sua quase totalidade, uma visão negativa da índole do trabalhador nacional, embora essa situação seja passível de reversão dependendo dos meios a serem utilizados: por meio da violência coatora das leis, ou por meio de outras estratégias que serão analisadas mais à frente em virtude de revelarem uma percepção mais acurada da questão.

As críticas se concentram na pouca disposição ao trabalho, demonstrada pelos trabalhadores nacionais, por contraposição ao apego ao trabalho demonstrado pelo trabalhador europeu. Muito sintomática é a discussão sobre a imigração do trabalhador chinês, chins ou coolies, reveladora de um nível assustador de preconceito, só ultrapassado na análise de um ou outro observador mais atento e que não faz coro com o senso comum.

O trabalhador brasileiro é visto como avesso ao trabalho sistemático, não se preocupa em melhorar a própria vida, em progredir, jaz na incivilidade, no consumo de umas poucas coisas que o seu parco salário permite comprar, complementado pela prodigalidade da natureza. Para muitos, entregar o futuro da lavoura ao seu labor é expressão de imprudência escancarada.

Em tais condições, confiar a sorte da lavoura somente a um elemento incerto, como é o trabalho nacional que, sem o estímulo das necessidades impostas pela civilização, com dificuldade se entrega a serviço continuado, não é ainda o modo, na opinião de alguns, de resolver o problema do trabalho (Congresso Agrícola, 1988, p. 129). ${ }^{7}$

$\mathrm{Na}$ realidade, trata-se de uma mistificação do assunto. Por que essa resistência do trabalhador livre nacional ao trabalho na forma como desejavam os proprietários e por que se satisfaz com os parcos recursos hauridos no trabalho ocasional ou na coleta do que prodigaliza a natureza?

Naturalizar essa resistência é não compreender as raízes sociais e culturais profundas que elucidam a questão. Os discursos dos proprietários de terra, algumas vezes deixam escapar concepções que revelam uma compreensão mais profunda do assunto, impedindo a explicação recair para o argumento do mero naturalismo da inoperância do trabalhador nacional.

(7) Fala do ministro da agricultura e presidente do conselho de ministro, João Lins Vieira Cansansão de Sinimbu, na abertura da $1^{\text {a }}$ sessão, em 8 de julho de 1878. 
Numa sociedade escravista, o trabalho é encarado como um atributo do escravo. O homem livre se define pelo não-trabalho, pela ocupação de posição de mando e direção, ou execução de tarefas que não guardam qualquer similaridade com as exercidas pelos escravos, como as atividades que exigem certa especialização, caso dos artesãos, ou as que se caracterizam pelo seu caráter não braçal, como no caso dos profissionais liberais. Em quaisquer delas o ócio é uma realidade esperada, uma vez que o trabalho não ocupa todo tempo do trabalhador, e, sobretudo, pela possibilidade de controle do processo, do ritmo e do tempo de trabalho, que revela a autonomia que esses profissionais detêm, o que constitui para os escravos uma miragem impraticável na sua condição de não proprietário da sua própria pessoa. Na prática cotidiana, a situação do escravo é mais matizada e as formas como reage ao processo não seguem uma linha padronizada e retilínea como se fosse um autômato inerte, embora pese sobre o seu dia-a-dia as exigências do senhor nas condições do cativeiro, da qual o escravo não pode fazer tábula rasa.

O trabalhador livre tem consciência da sua situação e do seu status diferenciados dos do escravo, apesar da sua pobreza. O seu referencial, constitutivo da sua auto-estima, dificulta qualquer aproximação com a situação do escravo. Significativamente, em uma sociedade escravista, quem pode torna-se senhor, embora as gradações do ser senhor estejam presentes. Um senhor de poucos escravos, ou de um escravo, não se compara com o proprietário poderoso, mas com os que estão próximos socialmente. Antonil expressou a ansiedade pela busca dos meios para tornar-se senhor no interior da sociedade escravista do seu tempo em função da respeitabilidade inerente que acompanha os que o conseguem.

Saint-Hilaire, em visita à comarca do Rio das Mortes, sul de Minas, notou certa relação de proximidade entre escravos e livres:

... o povo geralmente mais sujo é também muito menos civilizado. Nesta última, os habitantes dos campos aplicam-se mais à agricultura. Trabalham com seus negros e passam a vida nas plantações, no meio dos animais, e seus costumes tomam, necessariamente, algo da rusticidade das ocupações (Saint-Hilaire, 1974b, p. 37).

Esta concepção é, todavia, problemática. Embora houvesse convivência entre senhores e escravos, como ficou claro acima, a distância entre um homem livre e um escravo era imensa, como notou o próprio Saint-Hilaire, ao perceber o caráter violento e desumano da escravidão:

Ficam os escravos a infinita distância dos homens livres, são burros de carga a quem se despreza, acerca de quem se crê só podem ser levados pela arrogância e ameaças. Um brasileiro, assim, poderá ser caridosíssimo para com um homem de sua raça e ter muito pouca pena de seus negros a quem não considera como semelhantes (Saint-Hilaire, 1974b, p. 51). 
Essa reflexão de Saint-Hilaire, que toca o cerne da questão da escravidão, foi feita por ocasião de uma cena por ele presenciada, de uma mulher que com ele fora sensata e amável, mas que mal colocou os pés em casa, prorrompeu em xingamentos as suas escravas. Pouco tempo depois ele presenciou outra cena reveladora do caráter desumano da escravidão, como fator que pressiona pela destruição da auto-estima e da personalidade do negro escravo. Ao chegar em uma casa, na qual pernoitou, "A dona da casa, antes de partir, tivera o cuidado de enclausurar as suas negras..." (Saint-Hilaire, 1974b, p. 47).

Para o trabalhador livre, a condição do escravo se constitui num marco instransponível.

O senhor Joaquim José Álvares do Santos, de Leopoldina, Minas Gerais, ao expor suas opiniões no Congresso Agrícola do Rio de Janeiro, salientou que:

O nosso povo é de um natural indolente e não se presta ao serviço da agricultura. Os operários nacionais entendem que com esse serviço se degradam e não o querem prestar, preferindo comer lá no seu canto um pedaço de rapadura e beber uma xícara de café, a adquirir por meio do trabalho agrícola nas fazendas os meios de alimentarem-se melhor em suas choupanas (Congresso Agrícola, 1988, p. 155).

Por que o sentimento de degradação? O que há na faina agrícola, em si, que desabona quem a ela se dedica, senão o fato de ser ela identificada com o trabalho escravo?

Muito significativa é a análise que o Sr. João Batista Braziel fez, no mesmo Congresso, sobre a situação dos ingênuos. À questão sobre a possibilidade de se utilizar o seu trabalho como meio de amenizar a crise da falta de braços para a lavoura, afirmação que foi questionada no Congresso, ele responde:

O serviço que os ingênuos podem prestar à lavoura é problemático ... porque, desde que elles obtenham a emancipação, a primeira cousa que devem querer alcançar é a liberdade, de que se acham privados desde seus pais. Hão de sentir talvez mais tarde, necessidade de pão; a mão da justiça e os deveres sociais hão de obrigal-os a procurar trabalho, e elles recorrerão à lavoura (Congresso Agrícola, 1988, p. 144).

Trata-se de não se identificar com a ocupação que indica o status de escravo de quem a executa. Se mesmo para o ingênuo emancipado a liberdade pode significar a possibilidade de não executar as tarefas próprias do labor dos escravos, muito maior resistência pode se esperar do homem livre.

Além deste componente cultural e psicológico, há um outro, especificamente econômico, que se tornou um forte estimulador da recusa ao trabalho sistemático por parte dos trabalhadores livres na forma como desejavam os proprietários.

Era compensador? O salário era estimulante? Ou os proprietários procuravam estender para homens livres relações próprias do escravismo, à qual secularmente estavam adestrados pelo seu modus operandi? 
Por meio de discursos em jornais e no Congresso Agrícola, pode-se perceber a falta de estímulos econômicos como fator inibidor da disposição do homem livre em se dedicar ao trabalho no padrão desejado pelos proprietários. Como contraponto às condições precárias de remuneração do trabalho, os homens livres construíam um outro modelo de como ganhar a vida. Sem as condições materiais que lhes permitissem inserção no mercado e adoção de uma perspectiva de acumulação de riqueza, a sua racionalidade se pautava por outros parâmetros. Produção em pequena escala de artigos que pudessem ser vendidos para apurar meios necessários à aquisição dos elementos mais básicos à sobrevivência, produção de artigos de subsistência, caça, pesca, conversa nas vendas, cantorias, liberdade em dispor do próprio tempo, possibilidade de mobilidade espacial, em conjunto, se constituíam nos componentes básicos do seu jeito de viver (Moura, 1998, p. 71-98; Mattos, 1998, p. 27-54).

Na crise do trabalho escravo que se agudizou após a aprovação da lei do Ventre-livre, um certo tom apocalíptico tomou conta dos discursos dos que pintavam com cores fortes e dramáticas o futuro nada auspicioso da lavoura brasileira. A busca de soluções abarcou um campo amplo que se estendia da ação em prol da imigração, aquisição de escravos das regiões menos promissoras, uso do trabalho dos ingênuos, até a utilização do trabalhador nacional. Era muito forte a descrença na capacidade do trabalhador nacional ser utilizado como opção para resolver a questão da falta de braços, mas não era consensual a opção pela utilização do trabalho do imigrante. No Congresso Agrícola do Rio de Janeiro não foram poucas as dissensões e afirmação na descrença em relação à solução imigrantista, que, a rigor, só em SP foi implantada de forma mais intensa (Lanna, 1988, p. 45-73).

Não foram raras as vozes que perceberam a factibilidade da utilização do trabalhador livre nacional que, mediante certas condições, poderia se tornar merecedor de confiança e em nada seria inferior ao trabalhador estrangeiro. Todos os que se expressaram assim apontaram para a necessidade de dar incentivos ao trabalhador livre como forma de engajá-lo no processo produtivo de maneira confiável. Incentivos que abarcam desde a isenção do serviço militar até a indicação da necessidade de salários melhores, ou implantação de sistemas de trabalho capazes de abrir perspectivas de ganhos mais substanciais.

Ao ser colocada desta forma, desmistifica-se a concepção da indolência natural do trabalhador nacional, da sua incapacidade para o trabalho sistemático. $\mathrm{O}$ que emerge, então, são condições sociais e históricas que não exercem qualquer fator motivador para a dedicação ao trabalho, e quando essas teses são exaradas da análise de proprietários de terra, muito mais significativas se tornam. 
A Comissão dos lavradores do Rio de Janeiro, Minas Gerais, e Espírito Santo no Congresso expressa essa concepção da seguinte forma:

Seja-lhe, porém, permitido acrescentar desde já que urge promulgar uma boa lei de locação de serviços e adoptar medidas tendentes a chamar para a lavoura braços nacionaes que não deixarão de procurar esse emprego, desde que lhes forem oferecidos incentivos, como a dispensa do imposto de sangue e outros favores igualmente ambicionados pela nossa população (Congresso Agrícola, 1988, p. 78).

O Sr. Dr. Antônio Cesário de Faria Alvim, de Ubá, zona da mata de Minas, assim se expressa:

Dê-se o dinheiro que se gasta com a colonisação estrangeira aos nossos compatriotas; faça-me a colonização nacional. De dia em dia, de anno em anno, a escravidão vai se extinguindo, e os ex-escravos, pelas nossas leis, tornam-se cidadãos brasileiros. Convem que os aproveitemos dando-lhes vantagens, prêmios pecuniários. Ao redor ... encontra muitos homens que precisam ganhar dinheiro para viver compromettem-se a trabalhar mediante contracto, a cujo cumprimento negam-se mais tarde. É necessário obrigal-os a trabalharem, não empregando violência, mas garantindo-lhes a lei certas isenções e vantagens, tratando-os o Governo com carinho, animando-os ... Quem vive nas nossas cidades não conhece o povo brasileiro. Para conhecel-o é preciso ir aos Mattos e lá encontral-o alimentando-se com os produtos espontâneos do solo e recusando-se a trabalhar nos estabelecimentos ruraes, porque entende que o salário é muito pequeno. Portanto, se houver por parte do Governo promessa ou garantia de prêmios, os trabalhadores brasileiros irão procurar trabalho na agricultura (Congresso Agrícola, 1988, p. 132).

Há uma série de depoimentos no mesmo sentido e outros que exemplificam como em determinadas situações o trabalhador livre nacional é digno de confiança, capaz de responder ao que dele se espera.

O jornal Monitor sul-mineiro, editado na cidade de Campanha, em um dos seus editoriais, segue na mesma direção:

Temos animadoras e agradáveis notícias a respeito dos resultados excelentes obtidos exclusivamente pelo trabalho livre em fazendas existentes no município de Valença e sabemos que há muitas outras, não só da província de São Paulo como do Rio, tem iniciado esta salutar prática, oferecendo alguns resultados em tudo superiores aos obtidos pelas outras épocas, só com o auxílio do trabalho escravo. Sentir-nos-íamos contentes se nos fosse permitido registrar estes novos e criteriosos hábitos em fazendas do sul de Minas, onde é tão elevado e importante o número de indivíduos aptos para o trabalho da lavoura, e que entretanto Gastão a vida sacrificando-a a uma inércia que nem tem a virtude de lhes dar dias tranqüilos (n. 752,14 jun. 1885).

O artigo prossegue mostrando como proprietários e empregados livres têm a ganhar se um contrato de trabalho adequado for assinado e respeitado entre eles, permitindo a ambos auferir vantagens e se afirmar mutuamente como sujeitos responsáveis e laboriosos. 
O jornal O Conservador, também editado na cidade de Campanha, traz um longo artigo do senhor João Garcez dos Santos, transcrito do jornal do Comércio, no qual o autor sugere uma série de procedimentos para renovar a prática da agricultura e, aos poucos, promover uma revolução nas formas e no processo de produção, sem que os abalos da crise do escravismo se façam sentir de maneira mais aguda. Além de propor uma série de procedimentos racionalizadores do processo de trabalho, a grande novidade aduzida pelo proprietário é a forma como chama ao trabalho tanto os escravos quanto os homens livres. Além de lhes garantir dias da semana para cultivar seus produtos, fixou, para os homens livres, um salário que aumenta na proporção do produto fabricado (o açúcar). Para o escravo, que poderia cultivar seus produtos nos dias para isso designados, criou a possibilidade de cada um pagar aos poucos a própria liberdade.

Com esses procedimentos:

Encaminho-os a contento meu e para o nosso, por tal meio que o empregado fica adstricto ao chão da casa fabril, onde tem filiado seu interesse e sua melhor esperança; deixa de ser um vagabundo disposto a largar a casa e o amo da véspera, para tomar um outro, pelo simples engodo de uma casa nova, que lhe promete um vintém de mais. Os melhores empregados são aqueles que reúnem a aptidão física à prática... será difícil em terra pouco povoada, onde faltam braços, e onde os poucos que existem, não encontrando vantagens e fortes estímulos, com certeza deixarão a boa ordem de qualquer trabalho vigoroso pelos prazeres da caça, da pesca, da viola e do pandeiro (n. 87, 27 maio 1871).

O artigo é muito esclarecedor ao apontar para questões sociais a explicação do comportamento tanto do homem livre quanto do escravo. A naturalização dos comportamentos como inerentes à pessoa expressa a mistificação do tema ao não verificar os seus condicionamentos histórico-sociais.

De qualquer forma, o trabalho executado por escravos, em sua maior parte, nos setores mais dinâmicos da economia, tinha de ser preservado, gerado continuamente, reproduzido socialmente, como fator de máxima importância na continuidade da empresa produtiva de senhores e proprietários.

Entram em cena fatores que sinalizam para a importância dos costumes, da tradição, do jeito de fazer conhecido de todos, enfim, da cultura do escravismo. De tanto ser praticado, ser posto em operação, de se repetir continuamente, tornase senso comum, aceito pela coletividade como normal. Quantos, no período anterior à crise do escravismo, deixaram de achar natural a escravidão? Ou se com ela se confrontavam, percebiam o seu arraigamento profundo, impossível de ser destruído a não ser gradualmente? Como afirmara Joaquim Nabuco, a colocação da necessidade de cuidar do fim da escravidão, posta na ordem do dia pelo Imperador, na Fala do Trono de 1867, causou perplexidade sobre as classes produtoras. 
O escravismo, em função da sua dinâmica interna, ao subjugar a pessoa do outro a outrem, no ajuntamento de escravos em núcleos com maior ou menor número, e na vida pessoal vivida em contato direto com os senhores, só poderia ser mantido por ações que, em sua essência, são políticas. Por isso, a dimensão política do escravismo salta aos olhos. Como afirmaram Manolo Florentino e José Roberto Góes, a política estava à soleira da porta do senhor.

O componente político empregado para manter o escravismo foi o fator mais sensível às injunções das conjunturas, e das idiossincrasias pessoais e grupais. Relações entre sujeitos colocados de forma antagônica no espectro social implicam, essencialmente, em relação de poder. A forma como os sujeitos se relacionam na sociedade implica numa série de processos que vão da adesão e passa pela cooptação, manipulação, acomodação, assimilação, conflitos e violência. Estas formas de relação estão presentes em maior ou maior medida em todas as formações sociais. Dificilmente uma ou outra acontece isoladamente, pois as conjunturas variam, assim como variam as percepções, interesses e posturas subjetivas. Por isso é que não se pode deduzi-las de forma apriorística. Isto não significa colocar todas as formas de organização social, política e de trabalho sob o mesmo padrão. Numa relação escravista é esperado que a possibilidade do uso da violência seja muito mais plausível que em qualquer outra, a despeito do conceito de poder, como afirmara Weber, comportar o uso da força em última instância em qualquer sociedade.

\section{Referências bibliográficas}

\section{Livros e artigos de periódicos}

ARON, Raymond. Estudos políticos. 2. ed. Brasília: Editora da Universidade de Brasília, 1985.

CANO, Wilson. Ensaios sobre a formação econômica regional do Brasil. Campinas, SP: Editora da Unicamp, 2002.

CARVALHO, José Murilo de. Introdução. In: CONGRESSO AGRÍCOLA. Rio de Janeiro: Fundação Casa de Rui Barbosa, 1988.

DOUGLAS, Cole Libby. Transformação e trabalho em uma economia escravista. São Paulo: Brasiliense, 1988.

Sociedade e cultura escravista como obstáculos ao desenvolvimento econômico: notas sobre o Brasil oitocentista. Estudos Econômicos, São Paulo, v. 23, n. 3, set./dez. 1993.

FILHO, Gilberto G.; NETTO, Luiz R. Minas Gerais: índices de casamento da população livre e escrava na comarca do Rio das Mortes. Estudos Econômicos, São Paulo: v. 18, n. 3, set./dez. 1988. 
FLORENTINO, Manolo; GÓES, José Roberto. A paz nas senzalas. Famílias escravas e tráfico atlântico. Rio de Janeiro, c.1790 - c.1850. Rio de Janeiro: Paz e Terra, 1997.

FONSECA, Antônio Caetano da. Manual do agricultor de gêneros alimentícios ou méthodo da cultura mixta desses gêneros nas terras cansadas. Rio de Janeiro: Eduardo \& Henrique Laemmert, 1863.

FRAGOSO, João Luis Ribeiro. Homens de grossa aventura: aventura e hierarquia na praça mercantil do Rio de Janeiro (1790-1830). 2. ed. Rio de Janeiro: Civilização Brasileira, 1998.

FURTADO, Celso. Formação econômica do Brasil. 19. ed. São Paulo: Ed. Nacional, 1984.

GEBARA, Ademir. Escravidão: fugas e controle social. Estudos Econômicos, São Paulo, v. 18, n. especial, 1988.

GENOVESE, Eugene D. A terra prometida: o mundo que os escravos criaram. Rio de Janeiro: Paz e Terra, 1988.

GORENDER, Jacob. A escravidão reabilitada. São Paulo: Ática, 1990.

IGLESIAS, Francisco. Minas Gerais. In: HOLANDA, Sérgio Buarque de (Org.). História Geral da Civilização Brasileira. 5. ed. São Paulo: Difel, 1985. tomo II, $2^{\circ}$ volume.

KENNETH, Maxwell. A devassa da devassa: a inconfidência mineira, Brasil-Portugal 1750-1808. Rio de Janeiro: Paz e Terra, 1977.

JUNQUEIRA, Luiz Alberto Franco. Família Franco: genealogia e história. [s.n.t.], 1980.

LANNA, Ana Lúcia Duarte. A transformação do trabalho. Campinas, SP: Editora da Unicamp, 1988.

LARA, Sílvia Hunold. Campos da violência: escravos e senhores na capitania do Rio de Janeiro 1750-1808. Rio de Janeiro: Paz e Terra, 1988.

LEBRUN, Gerard. O que é poder. São Paulo: Abril Cultural/Brasiliense, 1984.

LENHARO, Alcir. As tropas da moderação: o abastecimento da Corte na formação política do Brasil, 1808-1842. São Paulo: Símbolo, 1979.

LIBBY, Douglas Cole. Transformação e trabalho em uma economia escravista. São Paulo: Brasiliense. 1988.

MARTINS, Maria do Carmo Salazar et al. População de Minas Gerais na segunda metade do século XIX: novas evidências. In: SEMINÁRIO SOBRE ECONOMIA MINEIRA, 10, Diamantina, MG, 2002. Disponível em: www.cedeplar.ufmg.br/diamantina2002/ textos.html

MARTINS, Roberto Borges. Minas Gerais, século XIX: tráfico e apego à escravidão numa economia não-exportadora. Estudos Econômicos, Instituto de Pesquisas Econômicas - USP, v. 13, n. 1, 1983. 
Isaías Pascoal

MATTOS, Hebe Maria. Das cores do silêncio: os significados da liberdade no sudeste escravista-Brasil século XIX. 2. ed. Rio de Janeiro: Nova Fronteira, 1998.

MATTOSO, Kátia M. de Queirós. Ser escravo no Brasil. 2. ed. São Paulo: Brasiliense, 1988.

PAIVA, Clotilde Andrade; GODOY, Marcelo Magalhães. Negociantes e tropeiros em um território de contrastes. O setor comercial de Minas Gerais no século XIX. Disponível em: www.cedeplar.ufmg.br/diamantina2002/textos.html

; KLEIN, Herbert S. Escravos e livres nas Minas Gerais do século XIX: Campanha em 1831. Estudos Econômicos, São Paulo, v. 22, jan./abr. 1992.

PASCOAL, Isaías. Economia agrária e poder político no sul de Minas: a formação de uma identidade política conservadora na primeira metade do século XIX. Dissertação (Mestrado)-Departamento de sociologia, IFCH, Unicamp, 2000.

PRADO JÚNIOR, Caio. História econômica do Brasil. 34. ed. São Paulo: Brasiliense, 1986.

Formação do Brasil contemporâneo. 20. ed. São Paulo: Brasiliense, 1987.

REZENDE, Francisco de Paula Ferreira de. Minhas recordações. Belo Horizonte: Itatiaia, São Paulo: Editora da Universidade de São Paulo, 1988.

SAHLINS, Marshall. O "pessimismo sentimental" e a experiência etnográfica: por que a cultura não é um "objeto" em via de extinção (parte I). Mana. Estudos de Antropologia Social, Rio de Janeiro, v. 3, n. 1, abr. 1997.

SAINT-HILAIRE, Auguste de. Viagens pelo distrito dos diamantes e litoral do Brasil. Belo Horizonte: Itatiaia; São Paulo: Editora da Universidade de São Paulo, 1974.

Viagem pelas províncias do Rio de Janeiro e Minas Gerais. Belo Horizonte: Itatiaia; São Paulo: Editora da Universidade de São Paulo, 1975.

Segunda viagem do Rio de Janeiro a Minas Gerais e a São Paulo,1822. Belo Horizonte: Itatiaia; São Paulo: Editora da Universidade de São Paulo, 1974.

SLENES. Robert W. Na senzala, uma flor: esperanças e recordações na formação da família escrava - Brasil sudeste, século XIX. Rio de Janeiro: Nova Fronteira, 1999.

Os múltiplos de porcos e diamantes: a economia escravista de Minas Gerais no século XIX. Cadernos IFCH - Unicamp, n. 17, jun. 1985.

Malungu, ngoma vem! África encoberta e descoberta no Brasil. Passim. Cadernos do Museu da Escravatura, Luanda, Ministério da Cultura, n. 1, 2000.

WERNECK, Francisco Peixoto de Lacerda (Barão de Pati do Alferes). Memória sobre a fundação de uma fazenda na província do Rio de Janeiro. Brasília/Rio de Janeiro: Senado Federal, Casa de Rui Barbosa, 1985.

\section{Jornais}

O CONSERVADOR, n. 87, 27 maio 1871.

O DESPERTADOR, n. 6, 10 jun. 1886; n. 24, 14 out. 1886. 
OPINIÃO CAMPANHENSE, n. 366, 16 abr. 1836.

O SUL DE MINAS, n. 38, 8 abr. 1860.

MONITOR SUL-MINEIRO, n. 694, 2 abr. 1884; n. 702, 20 jul. 1884; n. 750, 31 maio 1885 ; n. 752,14 jun. 1885 ; n. 766,20 set. 1885 ; n. 768,4 out. 1885 ; n. 889,20 jan. 1888 ; n. 890,5 fev. 1888 ; n. 891, 12 fev. 1888 ; n. 894, 4 mar. 1888.

RECOPILADOR MINEIRO, n. 225, 2 maio 1835.

\section{Atas, congresso e relatórios}

CONGRESSO AGRÍCOLA, Rio de Janeiro, 1878. Anais. Rio de Janeiro: Fundação Casa de Rui Barbosa, Ed. Faccimilar, 1988.

RELATÓRIOS dos presidentes da Província de Minas Gerais de 1840-1900. Disponível em: www.crl.edu-content-brazil-mina.htm

\section{Revistas}

REVISTA DO ARQUIVO PÚBLICO MINEIRO, Ouro Preto, Imprensa Official de Minas Gerais, Anno 1, Fascículo 3ㅜ, jul./set. 1896.

REVISTA DO ARQUIVO PÚBLICO MINEIRO, Belo Horizonte, Imprensa Official de Minas Gerais, n. IV, 1899. Documentos Diversos. População da Província de Minas Gerais. 